\title{
Presence of Notahypsibius pallidoides (Tardigrada: Hypsibiidae) in the fauna of Russia confirmed with the methods of DNA barcoding
}

\author{
Denis Tumanov \\ Department of Invertebrate Zoology, Faculty of Biology, Saint Petersburg State University, \\ Universitetskaya nab., 7-9, Saint Petersburg, 199034, Russian Federation \\ Marine Research Laboratory, Zoological Institute of the Russian Academy of Sciences, \\ Universitetskaya nab., 1, Saint Petersburg, 199034, Russian Federation \\ Address correspondence and requests for materials to Denis Tumanov, d.tumanov@spbu.ru
}

\begin{abstract}
A brief report is given on the tardigrade species Notahypsibius pallidoides, discovered in a moss cushion in the vicinity of Saint Petersburg. Morphological identification of the species is supported with the analysis of obtained sequences of nuclear and mitochondrial DNA barcode genes (ITS-2 and COI). The current state of knowledge of Russian fauna of Tardigrada is characterised, and all available data on the distribution of Notahypsibius pallidoides and its genetic variability are summarised. The data obtained in this study by methods of DNA barcoding demonstrated that studied specimens of the tardigrada population isolated in Russia belong to the same species (Notahypsibius pallidoides) as the control specimens isolated in Austria though represent another haplotype thus confirming the presence of Notahypsibius pallidoides for the fauna of Russia.
\end{abstract}

Keywords: distribution, zoogeography, genetic variability, COI, ITS-2, Pilatobiinae

\section{Introduction}

Citation: Tumanov, D. 2021. Presence of Notahypsibius pallidoides (Tardigrada: Hypsibiidae) in the fauna of Russia confirmed with the methods of DNA barcoding. Bio. Comm. 66(3): 274-280. https://doi.org/10.21638/spbu03.2021.309

Author's information: Denis Tumanov, PhD, Researcher, orcid.org/0000-0002-41904175

Manuscript Editor: Pavel Skutschas, Department of Vertebrate Zoology, Faculty of Biology, Saint Petersburg State University, Saint Petersburg, Russia

Received: November 25, 2020;

Revised: January 28, 2021;

Accepted: February 5, 2021.

Copyright: (c) 2021 Tumanov. This is an open-access article distributed under the terms of the License Agreement with Saint Petersburg State University, which permits to the authors unrestricted distribution, and self-archiving free of charge.

Funding: No funding information provided.

Ethics statement: This paper does not contain any studies involving human participants or animals performed by any of the authors.

Competing interests: The authors have declared that no competing interests exist.

Phylum Tardigrada Doyère, 1840 is a group of microscopical multicellular animals. Tardigrades are widely distributed in nature, inhabiting marine and freshwater basins as well as terrestrial environments which contain (constantly or temporarily) free water (Nelson, Bartels and Guil, 2018). More than 1300 species of tardigrades have been described to date (Degma, Bertolani and Guidetti, 2009-2020), but the real taxonomic richness of this group is still underestimated because of the small number of active taxonomists and methodological difficulties (Guil and Cabrero-Sañudo, 2007; Bartels, Apodaca, Mora and Nelson, 2016).

Tardigrade fauna of Russia remains poorly investigated. Most of the published works were devoted to the European part of the territory (Biserov, 1991 and references within; Biserov, 1996a, 1997-98, 1999; Tumanov, 1997a, b, 2003, 2018; Kiosya and Inshina, 2008; Kiosya, 2009). Only a few publications were devoted to the Asian part of Russia (Biserov, 1992, 1996b, c, 1998; Abe, 2004; Kaczmarek, Michalczyk and Diduszko 2005, 2006; Biserov, Pilato and Lisi, 2011). In all abovementioned publications, taxonomical data were received using the traditional morphological approach. Until now there are only two published works, for the entire territory of Russia, in which the zoogeographical records are supported with DNA barcoding. One of them is primarily devoted to the phylogeny of the genus Milnesium (Morek and Michalczyk, 2019) and only confirms the presence of the species Mil. tardigradum Doyère, 1840 in Russia using an integrative taxonomy approach, i.e., with the analysis of both morphology and gene sequences. 
The other paper (Drohvalenko et al., 2019) is a perfunctory investigation, not focused specifically on Tardigra$\mathrm{da}$, and its results are impossible to interpret unambiguously. So, until now, the presence of only one tardigrade species is confirmed in Russia with the methods of DNA barcoding.

Since most of the faunistic records were published, tardigrade taxonomy has undergone significant changes. Numerous forms, previously accepted as widely distributed and polymorphic species (e.g., Macrobiotus hufelandi C. A. S. Schultze, 1834, Paramacrobiotus richtersi (Murray, 1911), Mesobiotus harmsworthi (Murray, 1907), Richtersius coronifer (Richters, 1903), Ramazzottius oberhaeuseri (Doyère, 1840), Hypsibius dujardini (Doyère, 1840), Mil. tardigradum, Pseudechiniscus suillus (Ehrenberg, 1853)), have now been proven to be complexes of similar species, poorly demarcated morphologically, but well-distinguishable with the methods of DNA barcoding (Bertolani, Rebecchi, Giovannini and Cesari, 2011; Gąsiorek et al., 2016, 2018; Kaczmarek et al., 2018; Stec, Morek, Gąsiorek and Michalczyk, 2018; Guidetti et al., 2019; Morek and Michalczyk, 2019; Cesari et al., 2020; Grobys et al., 2020; Roszkowska et al., 2020; Stec, Krzywański, Arakawa and Michalczyk, 2020; Tumanov, 2020a). Also, the presence of true cryptic species, completely undistinguishable in morphology, has been demonstrated in tardigrades (Bertolani, Rebecchi, Giovannini and Cesari, 2011; Guidetti et al., 2019). As the result, most of the zoogeographical records of such species should be considered as doubtful for the Russian territory, and it means that the investigation of tardigrade fauna of Russia should be started de novo, using molecular methods.

Still little is known on the genetic diversity of tardigrade species with confirmed wide distribution (Jørgensen, Mobjerg and Kristensen, 2007; Jørgensen et al., 2013; Cesari, Bertolani, Rebecchi and Guidetti, 2009; Cesari et al., 2016; Gąsiorek et al., 2016, Gąsiorek, Blagden and Michalczyk, 2019; Gąsiorek et al., 2019; Zawierucha et al., 2018; Jackson and Meyer, 2019; Morek et al., 2019; Kaczmarek et al., 2020; Pogwizd and Stec, 2020; Sugiura, Arakawa and Matsumoto, 2020; Sugiura, Minato, Matsumoto and Suzuki, 2020).

Recently, the tardigrade species Notahypsibius pallidoides (Pilato et al., 2011) was redescribed using an integrative approach, and its phylogenetic position was revised (Tumanov, 2020b). This species was originally described from Kherson Oblast, South Ukraine (Pilato et al., 2011). Later it was recorded in Minsk Oblast, Central Belarus (Pilato, Kiosya, Lisi and Sabella, 2012) and Sicily (Lisi, 2015). Moreover, distribution of this species was extended to Northwest Russia and Croatia (Tumanov, 2020b). For the integrative redescription, a newly revealed population from Austria was used. Also, the presence of this species is suspected for Poland (Tumanov, 2020b) and Ireland (Erica De Milio, unpublished data).
But whereas only the Austrian population has been characterized genetically so far (Tumanov, 2020b), it is possible that other records can represent cryptic species.

In summer 2020, 10 specimens and 2 exuvia with eggs of a species morphologically identical to Not. pallidoides were found in a moss sample from Pushkin city (vicinity of Saint Petersburg), close to the locality where the single specimen noted in the previous study ( $\mathrm{Tu}$ manov, 2020b) was found. In order to determine the taxonomical status of this species, sequences of two fastevolving genetic markers (mitochondrial - COI gene and nuclear - ITS-2) were obtained and compared with the available data on Not. pallidoides.

\section{Materials and methods}

\section{Sampling}

The moss sample was collected from stone in Pushkin city, vicinity of Saint Petersburg, Russia $\left(59^{\circ} 43^{\prime} 30,9^{\prime \prime} \mathrm{N}\right.$ $30^{\circ} 23^{\prime} 32^{\prime \prime} \mathrm{E}$ ), on November 21, 2019, and July 3, 2020. Material was stored within paper envelopes at room temperature. Tardigrade specimens were extracted from rehydrated samples using the standard technique of washing them through two sieves (first with $\approx 1 \mathrm{~mm}$ mesh size and second with $35 \mu \mathrm{m}$ mesh size; Tumanov, 2018). The contents of the finer sieve were examined under a Leica M205C stereomicroscope.

\section{Microscopy and imaging}

The tardigrades found in the moss sample were fixed with acetic acid and mounted on slides in Hoyer's medium. Light microscopy (LM): resulting permanent slides were examined under a Leica DM2500 microscope equipped with phase contrast $(\mathrm{PhC})$ and differential interference contrast (DIC). Photographs were made using a Nikon DS-Fi3 digital camera with NIS-Elements ${ }^{\text {Tw }}$ software (Nikon, Japan).

\section{Genotyping}

DNA was extracted from four individual animals using QuickExtract ${ }^{\mathrm{Ti}}$ DNA Extraction Solution (Lucigen Corporation, USA) using the modified protocol kindly provided by Torbjørn Ekrem, Norwegian University of Science and Technology.

1) Tardigrades were sorted in water and specimens were rinsed individually in $\mathrm{ddH}_{2} \mathrm{O}$.

2) Each individual specimen was transferred by pipette into a PCR-tube containing $70 \mu$ l QuickEx$\operatorname{tract}^{\text {Tix }}$.

3) PCR-tubes were vortexed well, spun down (5 min at $3500 \mathrm{RPM})$, then placed in TS-100C ThermoShaker $\left(30^{\circ} \mathrm{C}\right.$; $\left.300 \mathrm{RPM}\right)$ for $1 \mathrm{hr}$. 

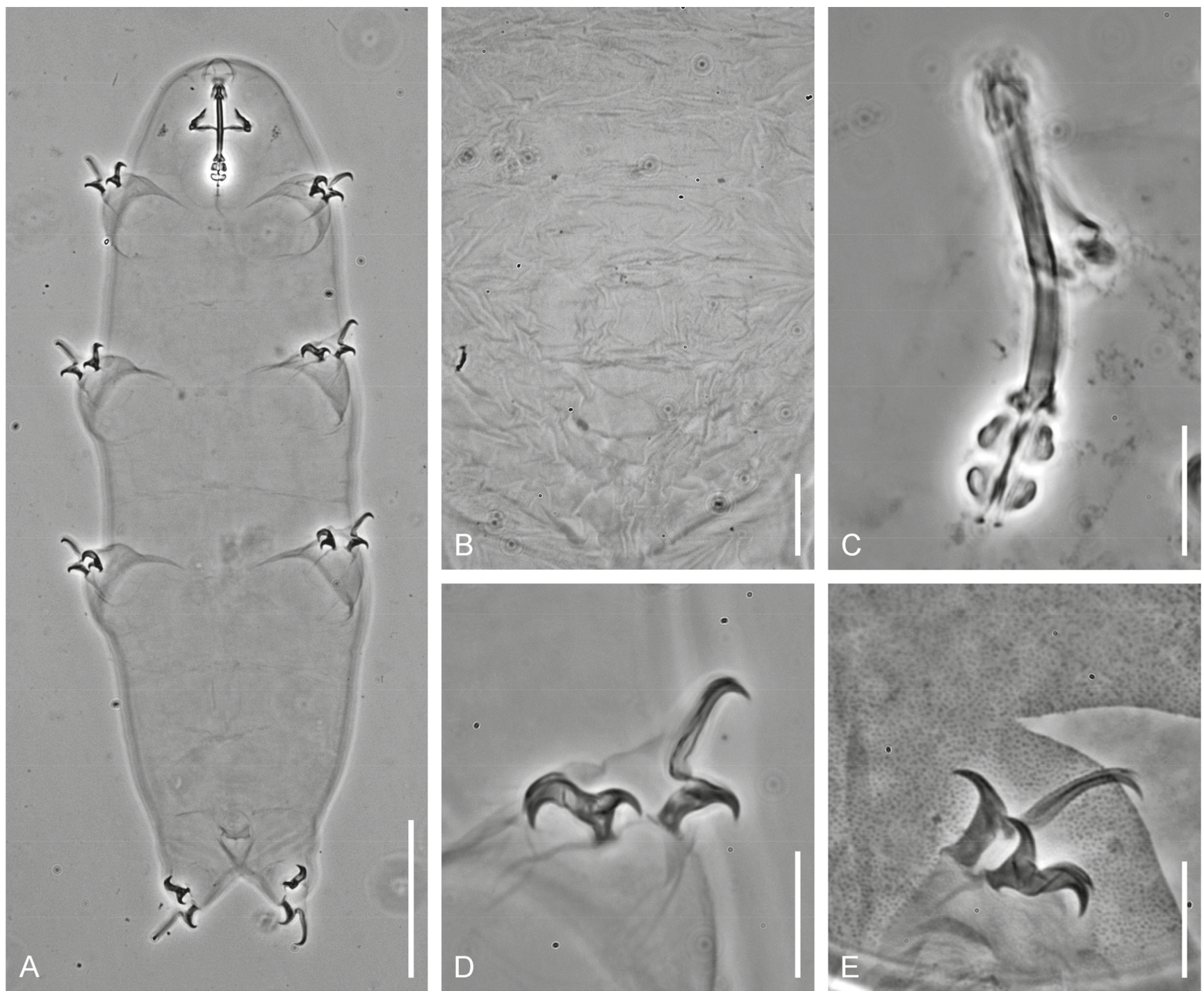

Fig. 1. Notahypsibius pallidoides, details of morphology (PhC). A - total view; B - dorsal cuticular sculpture; C - buccal-pharyngeal apparatus, lateral view; D - claws of leg II; E - claws of leg III and fragment of the egg chorion. Scale bars: A - $50 \mu \mathrm{m}, . \mathrm{B}-\mathrm{E}-10 \mu \mathrm{m}$.

Table 1. Primers and PCR programs used for amplification of the gene fragments sequenced in the study

\begin{tabular}{l|l|l|l|l|l}
\hline Gene & Primer name & $\begin{array}{c}\text { Primer } \\
\text { direction }\end{array}$ & \multicolumn{1}{|c|}{ Primer sequence (5'-3') } & \multicolumn{1}{c}{$\begin{array}{c}\text { Primer } \\
\text { source }\end{array}$} & \multicolumn{1}{c}{$\begin{array}{c}\text { PCR } \\
\text { programme }\end{array}$} \\
\hline COI & COI_Mes.rev_Ff & forward & AATTTGAGCTGCAACAGTAGG & Michalczyk, \\
& COI_Mes.rev_Rr & reverse & GAATAAGTGTTGGTATAAAATTGG et & $\begin{array}{l}\text { Wełnicz, } \\
\text { Frohme, and } \\
\text { Kaczmarek, 2016 }\end{array}$ \\
\hline ITS-2 & ITS2_Eutar_Ff & forward & CGTAACGTGAATTGCAGGAC & $\begin{array}{l}\text { Stec, Morek, } \\
\text { Gąsiorek and } \\
\text { Michalczyk, } \\
\text { 2018 }\end{array}$ & $\begin{array}{l}\text { Stec, Morek, } \\
\text { Gąsiorek and } \\
\text { Michalczyk, } \\
\text { 2018 }\end{array}$ \\
\hline & ITS2_Eutar_Rr & reverse & TGATATGCTTAAGTTCAGCGG & &
\end{tabular}




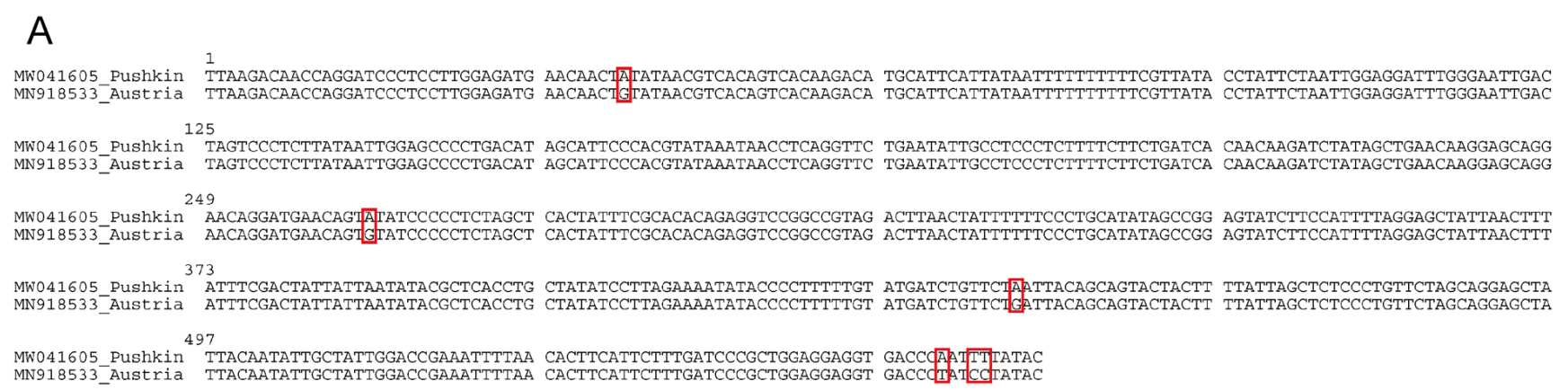

B

MW041569_Puskin I AATTGCAGGACTTTGCGAACGTTAATTCTT CGAACGCACATTGCGGCTTTGGGTTGACTG AAGCCACGCCTGGTTGAGGGTCAGTTGAAT AAACCATCACGATTGTATGTGTGTTGATCG MN927182_Austria AATTGCAGGACTTTGCGAACGTTAATTCTT CGAACGCACATTGCGGCTTTGGGTTGACTG AAGCCACGCCTGGTTGAGGGTCAGTTGAAT AAACCATCACGATTGTATGTGTGTTGATCG 121 MW041569 Puskin TGGAGTGTCCGGATAACGCGCTTGTCGCGT TAGCGGATCAAGTCGAGTCCGGATGTGGCT CGCGGCAGCTTGGCTTGGCCGAGTGTGTGC TTTCGTCGATTGGGACGTTAGGCCTCCTGT MN927182 Austria TGGAGTGTCCGGATAACGCGCTTGTCGCGT TAGCGGATCAAGTCGAGTCCGGATGTGGCT CGCGGCAGCTTGGCTTGGCCGAGTGTGTGC TTTCGTCGATTGGGACGTTAGGCCTCCTGT

Mw041569 Puskin 241 GCACATGCACCGCAGCTGCATCGCATAGGA GTGCTGGCCAATTCTGACGAGAGCCCGACT GGCTATATATAGAGTTGAGTGTACCGTGCA GCGCAATGACATTCGAGTGAATGCAAACGC MN927182_-Austria GCACATGCACCGCAGCTGCATCGCATAGGA GTGCTGGCCAATTCTGACGAGAGCCCGACT GGCTATATATAGAGTTGAGTGTACCGTGCA GCGCAATGACATTCGAGTGAATGCAAACGC 361

MW041569 Puskin 361 AAGAGAGAGTCTGCGGTGAGTGGCCTGGTC CGGTGCTCGCTTTACAGCTCTCTCAAGC-- AAAACATTAAATCATTCTTTTGACCTCAGC TCAGACGAGATTACCCGCTGAACT MN927182-Austria AAGAGAGAGTCTGCGGTGAGTGGCCTGGTC CGGTGCTCGCTTTACAGCTCTCTCAAGdAA AAAACATTAAATCATTCTTTTGACCTCAGC TCAGACGAGATTACCCGCTGAACT

Fig. 2. Comparison of the sequences of barcode genes of different populations of Notahypsibius pallidoides. A - COI; B - ITS-2. Variable positions are marked with red frames.

4) PCR-tubes were incubated at $65^{\circ} \mathrm{C}$ for $15 \mathrm{~min}$ in a PCR machine, vortexed every 5 min and spun down.

5) PCR-tubes were incubated at $98^{\circ} \mathrm{C}$ for $2 \mathrm{~min}$.

6) PCR-tubes were spun down (10 min at $4000 \mathrm{RPM})$.

7) $60 \mu \mathrm{l}$ of the extract supernatant were transferred into a new, sterile PCR tube. The supernatant was collected in order to avoid the exoskeleton remaining at the bottom. The PCR-tubes containing collected extract supernatant were then stored at $-20^{\circ} \mathrm{C}$ for later use in PCR.

8) $70 \mu \mathrm{lddH} \mathrm{H}_{2} \mathrm{O}$ were added to the tube with the exoskeleton and mixed well with the pipette to wash the exoskeleton.

9) Water and exoskeleton were transferred to a glass staining block with $\mathrm{ddH}_{2} \mathrm{O}$. The exoskeleton was collected and mounted on a microscope slide in Hoyer's medium and retained as the hologenophore (Pleijel et al., 2008).

Two barcode markers were sequenced from four specimens: internal transcribed spacer (ITS-2, nuclear), and the cytochrome oxidase subunit I gene (COI, mitochondrial). The primers and PCR programs used are provided in Table 1. COI sequences were translated to amino acids using the invertebrate mitochondrial code, implemented in SeaView 4.0 (Gouy, Guindon and Gascuel, 2010), in order to check for the presence of stop codons and therefore of pseudogenes.

PCR products were visualized in $1.5 \%$ agarose gel stained with ethidium bromide. All amplicons were sequenced directly using ABI PRISM Big Dye Terminator Cycle Sequencing Kit (Applied Biosystems, Foster City,
CA, USA) using an ABI Prism 310 Genetic Analyzer in the Core Facilities Center "Centre for Molecular and Cell Technologies" of St. Petersburg State University. Sequences were edited and assembled using ChromasPro software (Technelysium, USA).

Previously obtained sequences (Tumanov, 2020b) of the same markers for the Austrian population of the species Not. pallidoides (GeneBank accession numbers: MN927182 for ITS-2 and MN918533 for COI) were used for the comparison. Sequences were automatically aligned using the Muscle algorithm (Edgar, 2004) as implemented in SeaView 4.0. Uncorrected pairwise distances were calculated using MEGA7 (Kumar S, Stecher and Tamura, 2016) with gaps/missing data treatment set to "complete deletion".

Abbreviations of the tardigrade genera names are given according to Perry, Miller and Kaczmarek (2019).

\section{Results and discussion}

Specimens of the population investigated were morphologically identical to the Austrian population on Not. pallidoides (Fig. 1).

Sequences of both barcode markers (COI gene (GenBank accession number MW041605) and ITS-2 (GenBank accession number MW041569)) were obtained from four specimens. For both markers all obtained sequences were identical.

Comparison of fragments of the COI gene $(573 \mathrm{bp}$ length) and ITS-2 marker (474 bp length) with the sequences of the same markers of Not. pallidoides from Austria revealed close similarity of both populations. 
Calculated uncorrected pairwise distance for COI gene was $1.2 \%$. The nucleotide substitutions were: $\mathrm{A} / \mathrm{G}$ transitions in three nucleotide positions, T/C transition in two adjacent positions and $\mathrm{A} / \mathrm{T}$ transversion in one position (Fig. 2A). Translated amino acid sequences were identical for both haplotypes. Calculated uncorrected pairwise distance for ITS-2 was $0 \%$, but the sequences were actually not identical, containing one short indel (incertion/deletion) (Fig. 2B).

The genetic distances revealed for both analysed barcode markers lie within the intraspecific variability range currently accepted for tardigrades (Bertolani, Rebecchi, Giovannini and Cesari, 2011; Morek et al., 2019; Stec, Krzywański, Arakawa and Michalczyk, 2020). Evident similarity indicates that both populations (from Austria and from Russia), although represented by different haplotypes, should be attributed to the same species. Concluding, Not. pallidoides is now the second tardigrade species whose presence is confirmed for the fauna of Russia with the methods of DNA barcoding.

\section{Acknowledgements}

I thank Professor Torbjørn Ekrem (Norwegian University of Science and Technology) for providing me the unpublished DNA extraction protocol. I am thankful to anonymous reviewers for their valuable comments and corrections. This study was carried out with the use of equipment of the Core Facilities Center "Centre for Molecular and Cell Technologies" of St. Petersburg State University.

\section{References}

Abe, W. 2004. A new species of the genus Hypsibius (Tardigrada: Parachela: Hypsiibiidae) from Sakhalin Island, Far East Russia. Zoological Science 21:957-962. https://doi. org/10.2108/zsj.21.957

Bartels, P.J., Apodaca, J.J., Mora, C., and Nelson, D. R. 2016. A global biodiversity estimate of a poorly known taxon: Phylum Tardigrada. Zoological Journal of the Linnean Society 178:730-736. https://doi.org/10.1111/zoj.12441

Bertolani, R., Rebecchi, L., Giovannini, I., and Cesari, M. 2011. DNA barcoding and integrative taxonomy of Macrobiotus hufelandi C. A. S. Schultze 1834, the first tardigrade species to be described, and some related species. Zootaxa 2997:19-36. https://doi.org/10.11646/zootaxa.2997.1.2

Biserov, V. I. 1991. An annotated list of Tardigrada from European Russia. Zoologische Jahrbuecher 118:193-216.

Biserov, V.I. 1992. A new genus and three new species of tardigrades (Tardigrada: Eutardigrada) from the USSR. Bollettino di Zoologia 59:95-103. https://doi. org/10.1080/11250009209386654

Biserov, V. I. 1996a. Tardigrada of the Novaya Zemlya Archipelago, collected by the Marine Arctic Complex Expedition in 1994. Arthropoda Selecta 5:151-157.

Biserov, V.I. 1996b. Tardigrades of the Taimyr Peninsula with description of two new species. Zoological Journal of the Linnean Society 116:215-237. https://doi. org/10.1111/j.1096-3642.1996.tb02345.x

Biserov, V. I. 1996c. Macrobiotus lorenae sp. n., a new species of Tardigrada (Eutardigrada Macrobiotidae) from the Russian far East. Arthropoda Selecta 5:145-149.
Biserov, V. I. 1997-98. Tardigrades of the Caucasus with a taxonomic analysis of the genus Ramazzottius (Parachela: Hypsibiidae). Zoologischer Anzeiger 236:139-159.

Biserov, V. I. 1998. The Tardigrada of Komondorskiye Islands, with a description of Dactylobiotus dervizi, sp. nov. (Eutardigrada, Macrobiotidae). Entomologische Mitteilungen aus dem Zoologischen Museum Hamburg 12:327-336.

Biserov, V. I. 1999. A review of the Tardigrada from Novaya Zemlya; with description of three new species and an evaluation of the state of the environment in the region. Zoologischer Anzeiger 238:169-182.

Biserov, V.I., Pilato, G., and Lisi, O. 2011. Macrobiotus trunovae sp.n., a new species of tardigrade from Russia. Invertebrate Zoology 8(1):57-62. https://doi.org/10.15298/ invertzool.08.1.07

Cesari, M., Bertolani, R., Rebecchi, L., and Guidetti, R. 2009. DNAbarcoding in Tardigrada: the first case study on Macrobiotus macrocalix Bertolani and Rebecchi 1993 (Eutardigrada, Macrobiotidae). Molecular Ecology Resources 9:699-706. https://doi.org/10.1111/j.17550998.2009.02538.x

Cesari, M., McInnes, S., Bertolani, R., Rebecchi, L., and Guidetti, R. 2016. Genetic diversity and biogeography of the south polar water bear Acutuncus antarcticus (Eutardigrada: Hypsibiidae) - evidence that it is a truly pan-Antarctic species. Invertebrate Systematics 30:635-649. https:// doi.org/10.1071/IS15045

Cesari, M., Montanari, M., Kristensen, R. M., Bertolani, R., Guidetti, R., and Rebecchi, L. 2020. An integrated study of the biodiversity within the Pseudechiniscus suillus-facettalis group (Heterotardigrada: Echiniscidae). Zoological Journal of the Linnean Society 188:717-732. https://doi. org/10.1093/zoolinnean/zlz045

Degma, P., Bertolani, R., and Guidetti, R. 2009-2020. Actual checklist of Tardigrada species. $38^{\text {th }}$ Edition. https://doi. org/10.25431/11380_1178608

Drohvalenko, M., Mykhailenko, A., Rekrotchuk, M., Shpak, L., Shuba, V., Trokhymchuk, R., Utevsky, S., and Zinenko, O. 2019. Application of DNA barcoding in taxonomy and phylogeny: an individual case of COI partial gene sequencing from seven animal species. Vestnik Zoologii 53:375-384. https://doi.org/10.2478/vzoo-2019-0034

Edgar, R.C. 2004. MUSCLE: multiple sequence alignment with high accuracy and high throughput. Nucleic Acids Research 32:1792-1797. https://doi.org/10.1093/nar/ gkh340

Gąsiorek, P., Stec, D., Morek, W., Zawierucha, K., Kaczmarek, Ł., Lachowska-Cierlik, D., and Michalczyk, Ł. 2016. An integrative revision of Mesocrista Pilato, 1987 (Tardigrada: Eutardigrada: Hypsibiidae). Journal of Natural History 50:2803-2828. https://doi.org/10.1080/00222933.2 016.1234654

Gąsiorek, P., Stec, D., Morek, W., and Michalczyk, Ł. 2018. An integrative redescription of Hypsibius dujardini (Doyère, 1840), the nominal taxon for Hypsibioidea (Tardigrada: Eutardigrada). Zootaxa 4415:45-75. https://doi. org/10.11646/zootaxa.4415.1.2

Gąsiorek, P., Blagden, B., and Michalczyk, Ł. 2019. Towards a better understanding of echiniscid intraspecific variability: a redescription of Nebularmis reticulatus (Murray, 1905) (Heterotardigrada: Echiniscoidea). Zoologischer Anzeiger 283:242-255. https://doi.org/10.1016/j.jcz.2019.08.003

Gąsiorek, P., Jackson, K. J., Meyer, H. A., Zając, K., Nelson, D. R., Kristensen, R. M., and Michalczyk, Ł. 2019. Echiniscus virginicus complex: the first case of pseudocryptic allopatry and pantropical distribution in tardigrades. Biological Journal of the Linnean Society 128:789-805. https://doi. org/10.1093/biolinnean/blz147 
Gouy, M., Guindon, S., and Gascuel, O. 2010. SeaView version 4: A multiplatform graphical user interface for sequence alignment and phylogenetic tree building. Molecular Biology and Evolution 27:221-224. https://doi.org/10.1093/ molbev/msp259

Guidetti, R., Cesari, M., Bertolani, R., Altiero, T., and Rebecchi, L. 2019. High diversity in species, reproductive modes and distribution within the Paramacrobiotus richtersi complex (Eutardigrada, Macrobiotidae). Zoological Letters 5:1. https://doi.org/10.1186/s40851-018-0113-z

Grobys, D., Roszkowska, M., Gawlak, M., Kmita, H., Kepel, A., Kepel, M., Parnikoza, I., Bartylak, T., and Kaczmarek, Ł. 2020. High diversity in the Pseudechiniscus suillus-facettalis complex (Heterotardigrada; Echiniscidae) with remarks on the morphology of the genus Pseudechiniscus. Zoological Journal of the Linnean Society 188:733-752. https://doi.org/10.1093/zoolinnean/zlz171

Guil, N. and Cabrero-Sañudo, F. 2007. Analysis of the species description process of a little known invertebrate group: the limnoterrestrial tardigrades (Bilateria, Tardigrada). Biodiversity and Conservation 16:1063-1086. https://doi. org/10.1007/s10531-006-9069-y

Jackson, K.J. and Meyer, H.A. 2019. Morphological and genetic analysis of Milnesium cf. granulatum (Tardigrada: Milnesiidae) from Northeastern North America. Zootaxa 4604:497-510. https://doi.org/10.11646/zootaxa.4604.3.6

Jørgensen, A., Mobjerg, N., and Kristensen, R. M. 2007. A molecular study of the tardigrade Echiniscus testudo (Echiniscidae) reveals low DNA sequence diversity over a large geographical area. Journal of Limnology 66:77-83. https://doi.org/10.4081/jlimnol.2007.s1.77

Jørgensen, A., Faurby, S., Persson, D. K., Halberg, K. A., Kristensen, R. M., and Møbjerg, N. 2013. Genetic diversity in the parthenogenetic reproducing tardigrade Echiniscus testudo (Heterotardigrada: Echiniscoidea). Journal of Limnology 72:136-143. https://doi.org/10.4081/jlimnol.2013.s1.e17

Kaczmarek, L., Michalczyk, L., and Diduszko, D. 2005. Some tardigrades from Siberia (Russia, Baikal region) with a description of Macrobiotus garynahi sp. nov. (Eutardigrada: Macrobiotidae: richtersi group). Zootaxa 1053:35-45. https://doi.org/10.11646/zootaxa.1053.1.3

Kaczmarek, L., Michalczyk, L., and Diduszko, D. 2006. Ramazzottius bunikowskae, a new species of Tardigrada (Eutardigrada, Hypsibiidae) from Russia. Zootaxa 1229:49-57. https://doi.org/10.11646/zootaxa.1229.1.4

Kaczmarek, Ł., Zawierucha, K., Buda, J., Stec, D., Gawlak, M., Michalczyk, Ł., and Roszkowska, M. 2018. An integrative redescription of the nominal taxon for the Mesobiotus harmsworthi group (Tardigrada: Macrobiotidae) leads to descriptions of two new Mesobiotus species from Arctic. PLOS ONE 13:e0204756. https://doi.org/10.1371/journal. pone.0204756

Kaczmarek, Ł., Mioduchowska, M., Kačarević, U., Kubska, K., Parnikoza, I., Gołdyn, B., and Roszkowska, M. 2020. New records of Antarctic Tardigrada with comments on interpopulation variability of the Paramacrobiotus fairbanksi Schill, Förster, Dandekar and Wolf, 2010. Diversity 12:108. https://doi.org/10.3390/d12030108

Kiosya, Y. O. 2009. New records of tardigrades (Tardigrada) for the territory of Crymean peninsula. Ecosisiemy, ih optimizatsiya i ohrana 20:25-31. (In Russian)

Kiosya, Y. O. and Inshina, V. V. 2008. First record of Macrobiotus beotiae Durante and Maucci, 1979 (Tardigrada: Eutardigrada: Macrobiotidae) in Ukraine. Visnik Charkivskogo nacionalnogo universitetu imeni V. N. Karazina. Seria: Biologia 7:100-103.

Kumar, S., Stecher, G., and Tamura, K. 2016. MEGA7: Molecular Evolutionary Genetics Analysis Version 7.0 for Bigger
Datasets. Molecular Biology and Evolution 33:1870-1874. https://doi.org/10.1093/molbev/msw054

Lisi, O. 2015. Current knowledge on the Sicilian tardigrade fauna. Biodiversity Journal 6:297-304.

Michalczyk, Ł., Wełnicz, W., Frohme, M., and Kaczmarek, Ł. 2012. Redescriptions of three Milnesium Doyere, 1840 taxa (Tardigrada: Eutardigrada: Milnesiidae), including the nominal species for the genus. Zootaxa 3154:1-20. https://doi.org/10.11646/zootaxa.3154.1.1

Morek, W. and Michalczyk, Ł. 2019. First extensive multilocus phylogeny of the genus Milnesium (Tardigrada) reveals no congruence between genetic markers and morphological traits. Zoological Journal of the Linnean Society 188:681-693. https://doi.org/10.1093/zoolinnean/zlz040

Morek, W, Stec, D, Gąsiorek, P, Surmacz, B., and Michalczyk, Ł. 2019. Milnesium tardigradum Doyère, 1840: The first integrative study of interpopulation variability in a tardigrade species. Journal of Zoological Systematics and Evolutionary Research 57:1-23. https://doi.org/10.1111/ jzs.12233

Nelson, D. R., Bartels, P. J., and Guil, N. 2018. Tardigrade Ecology. In: Schill R. O. (Ed). Water Bears: The Biology of Tardigrades, Zoological Monographs 2:163-210. Springer Nature Switzerland AG. https://doi.org/10.1007/978-3319-95702-9_7

Perry, E., Miller, W. R., and Kaczmarek, Ł. 2019. Recommended abbreviations for the names of genera of the phyIum Tardigrada. Zootaxa 4608:145-154. https://doi. org/10.11646/zootaxa.4608.1.8

Pilato, G., Kiosya, Y., Lisi, O., Inshina, V., and Biserov, V. 2011. Annotated list of Tardigrada records from Ukraine with the description of three new species. Zootaxa 3123:1. https://doi.org/10.11646/zootaxa.3123.1.1

Pilato, G., Kiosya, Y., Lisi, O., and Sabella, G. 2012. New records of Eutardigrada from Belarus with the description of three new species. Zootaxa 3179:39-60. https://doi. org/10.11646/zootaxa.3179.1.2

Pleijel, F., Jondelius, U., Norlinder, E., Nygren, A., Oxelman, B., Schander, C., Sundberg, P., and Thollesson, M. 2008. Phylogenies without roots? A plea for the use of vouchers in molecular phylogenetic studies. Molecular Phylogenetics and Evolution 48:369-371. https://doi.org/10.1016/j. ympev.2008.03.024

Pogwizd, J. and Stec, D. 2020. New records of Dactylobiotus parthenogeneticus Bertolani, 1982 provide insight into its genetic variability and geographic distribution. Folia Biologica 68:57-72. https://doi.org/10.3409/fb_68-2.08

Roszkowska, M., Grobys, D., Bartylak, T., Gawlak, M., Kmita, H., Kepel, A., Kepel, M., Parnikoza, I., and Kaczmarek, Ł. 2020. Integrative description of five Pseudechiniscus species (Heterotardigrada: Echiniscidae: the suillus-facettalis complex). Zootaxa 4763:451-484. https://doi. org/10.11646/zootaxa.4763.4.1

Stec, D., Morek, W., Gąsiorek, P., and Michalczyk, Ł. 2018. Unmasking hidden species diversity within the Ramazzottius oberhaeuseri complex, with an integrative redescription of the nominal species for the family Ramazzottiidae (Tardigrada: Eutardigrada: Parachela). Systematics and Biodiversity 16:357-376. https://doi.org/10.1080/14 772000.2018.1424267

Stec, D., Krzywański, Ł., Arakawa, K., and Michalczyk, Ł. 2020. A new redescription of Richtersius coronifer, supported by transcriptome, provides resources for describing concealed species diversity within the monotypic genus Richtersius (Eutardigrada). Zoological Letters 6:2. https:// doi.org/10.1186/s40851-020-0154-y

Sugiura, K., Arakawa, K., and Matsumoto, M. 2020. Distribution of Macrobiotus shonaicus Stec, Arakawa and Michal- 
czyk, 2018 (Tardigrada: Eutardigrada: Macrobiotidae) in Japan. Zootaxa 4767:056-070. https://doi.org/10.11646/ zootaxa.4767.1.2

Sugiura, K., Minato, H., Matsumoto, M., and Suzuki, A. C. 2020. Milnesium (Tardigrada: Apochela) in Japan: the first confirmed record of Milnesium tardigradum s.s. and description of Milnesium pacificum sp. nov. Zoological Science 37:476-495. https://doi.org/10.2108/zs190154

Tumanov, D. V. 1997a. Tardigrades in freshwater bentic communities in Northwestern Russia. The response of lake ecosystems to changes in biotic and abiotic conditions. Trudy Zoologicheskogo Instituta RAN 272:330-333. (In Russian)

Tumanov, D. V. 1997b. Hypsibius iskandarovi sp. nov., a new species of Tardigrada from fresh waters of North-West Russia (Tardigrada: Hypsibiidae). Zoosystematica Rossica 5:219-220.

Tumanov, D. V. 2003. Four new Isohypsibius species from Russian fresh waters (Tardigrada, Hypsibiidae). Bulletin de I'Institut Royal des Sciences Naturelles de Belgique, Biologie 73:183-189.
Tumanov, D. V. 2018. Hypsibius vaskelae, a new species of Tardigrada (Eutardigrada, Hypsibiidae) from Russia. Zootaxa 4399:434. https://doi.org/10.11646/zootaxa.4399.3.12

Tumanov, D. V. 2020a. Analysis of non-morphometric morphological characters used in the taxonomy of the genus Pseudechiniscus (Tardigrada: Echiniscidae). Zoological Journal of the Linnean Society 188:753-775. https:// doi.org/10.1093/zoolinnean/zlz097

Tumanov, D. V. 2020b. Integrative redescription of Hypsibius pallidoides Pilato et al., 2011 (Eutardigrada: Hypsibioidea) with the erection of a new genus and discussion on the phylogeny of Hypsibiidae. European Journal of Taxonomy 681:1-37. https://doi.org/10.5852/ejt.2020.681

Zawierucha, K., Stec, D., Lachowska-Cierlik, D., Takeuchi, N., Li, Z., and Michalczyk, Ł. 2018. High mitochondrial diversity in a new water bear species (Tardigrada: Eutardigrada) from mountain glaciers in central Asia, with the erection of a new genus Cryoconicus. Annales Zoologici 68:179-201. https://doi.org/10.3161/00034541A NZ2018.68.1.007 